\title{
Federalism in 3D: The Reimagination of Political Community in the European Union
}

\section{NeIL WALKer}

Regius Professor of Public Law and the Law of Nature and Nations Edinburgh Law School

\section{CONTENTS}

1. The EU Polity in 3D

2. The Limits of EU federalism: technique and affect

3. The Federal Imagination

4. The EU Federal Imagination in 3D

5. The Challenge of sub-state independence movements to the 3D perspective

6. Restaging the Federal Imagination 


\section{The EU Polity in 3D}

The fit between the federal idea and the European Union has always been both obvious and awkward. It is obvious because there is so much about the European Union that appears to be federal in general character. A familiar and widely affirmed general definition of federalism holds it to be 'the genus of political organization that is marked by the combination of shared rule and self-rule't. In terms of that bare test, the European Union appears to qualify emphatically as a species of the federal genus. Its 28 Member States, all of whom continue to enjoy sovereign statehood in international law, and to that significant extent also continue to enjoy self-rule, have nevertheless pooled and so come to share substantial powers in various areas of law and public policy at the higher, supranational level. Reinforcing the federal pattern, a number of Member States also demonstrate a federal or federal-like structure of internal relations, including Germany, the EU's largest and most influential member, as well as Austria, Belgium, Spain, Italy and the United Kingdom. So federalism is a feature of the whole, but also of some of the parts.

Yet the European Union is also a very unusual, indeed unique species of the federal genus. On the one hand, by far the most common application of the federal idea is to the sovereign state. That is to say, the form of 'political organization' to which the federal label normally applies is the territorial state typical of the modern age, complete with a division of powers between a common government of the whole and geographically discrete internal 'cantons', 'cities', 'provinces', 'Länder' or even (and confusingly) 'states'. On the other hand, to the extent that the ' $f$ ' root is used with reference to forms of political organization other than states, the typical stylization remains 'confederation'. Confederation refers to a pooling or upward delegation of authority by a number of sovereign states towards a broader international authority, which is weaker than the centre of federal state in several important respects. Unlike the central government of the federal state, the confederation tends to be subject to member state veto on many issues. Its decisions bind member states but not their citizens directly. It lacks an independent fiscal or electoral base; and authority has been not ceded to it by the member states finally and irreversibly.

Both models - federal state and confederation - are in the final analysis the product of a sovereign state-centred perspective. In the one case (federal state), the sovereign state provides the framework for the entire federal relationship, whereas in the other (confederation) it provides the prior and dominant unit within the wider relationship. But if, under the sign of state sovereignty, federal 
state and confederation are the two main federal types, this leaves the EU in an uncharted place ${ }^{2}$. Lacking the omni-competence of a sovereign state but possessing a more autonomous institutional framework and more a more penetrative normative reach than a confederation, the EU, at least in the eyes of most observers ${ }^{3}$, conforms to neither of the two most familiar species of the federal genus. One way of putting this - albeit little explored - that captures a common distinction between the EU and both archetypes is to say that the kind of federalism with which the EU is associated is three-dimensional (3D) rather than the more familiar two dimensional (2D) structure. Both the federal state and the confederation imply two-level systems - in the one case the central state (the federal government) and its sub-state parts, and in the other the supra-state (the confederal institutions) and the (sovereign) state, whereas the EU recognizes (and reframes) all three of the levels implicated in this pair of two-level systems supra-state, state and sub-state.

Hence the awkwardness in applying the federal idea to the EU - an awkwardness reflected in the range of labels that have been used in this endeavour. The EU has been called 'quasi-federal', a 'loose federation', an example of 'partial federalism', a case of 'federalism without a federation', 'a Federation of States', and a 'federation d'état-nations' 9 . To complicate matters further, federal theory also tends to lay claim ${ }^{10}$ to various other descriptors as part of a broader innominate category of federal types, and many such descriptors have also been applied to the EU. So where the EU has been described as a Union, a league, a Bund ${ }^{11}$, 'a compound democracy'12, a 'transnational consociation',

\footnotetext{
2 See e.g. the discussion of R. SCHÜTZE (2012), p. 2.
}

3 Some do revert to the unqualified labels. For Daniel Elazar and for Michael Burgess, for example, the EU is simply a 'confederation', whereas for Thomas Hueglin and Alain Fenna it is simply a 'federation'. See e.g. M. Burgess (2000); D. Elazar (2008); T. Hueglin and A. FennA (2006); and for general discussion, see J. Law, 'How Can we Define Federalism?' (2013).

4 See e.g. J. McCormick (2011) and D. McKaY (2001).

5 W. Wallace (1996), pp. 439-60.

6 J.C. PIRIS (2006), pp. 69-87.

7 E. Bomberg, J.Peterson and A. StubBs (2008).

8 See SchüтzE n2 above but also at the political level, among others famously by Joskcha Fischer, then German Foreign Minister, in his Humboldt speech of 2000 , which is seen as catalyst for the European constitutional project of that decade. https://www.google.co.uk/webhp?sourceid=chromeinstant\&ion $=1$ \&espv=2\&ie=UTF-8\#q=Josjcha+Fischer+confedration .

9 See O. BEAUd (2007).

10 See e.g. A. Follesdal, Federalism.

11 M. Avbelj (2011), pp. 818-36.

12 S. FABBrinI (2007) and A. GLenCross (2009).

13 See e.g. R. Demousse (1998), p. 595. 
a 'post-Hobbesian non-state'14, a 'commonwealth'15, a case of 'constitutional pluralism'16, or even as a previously 'unidentified political object'17, what is arguably being suggested, just as when the nominate-with-modifiers labels are invoked, is the way in which the EU imperfectly approximates an existing federal type.

But what, if anything, is at stake in this definitional disputation, and what are those involved seeking to accomplish? Certainly, if the aim is simply the detached one of locating the EU within a typological or taxonomical scheme of (federal) polity types, the point and the potential dividend would be unclear. Either the candidate labels, - 'f' word or not, and, if 'f', with or without key modifiers - are merely suggestive of certain important features of the supranational body politic but not intended to be mutually exclusive, still less exhaustive in their referential scope, in which case there is not much of moment in the choice and little worth fighting over. Or the labels are intended as strong descriptions and are meant to be mutually exclusive. But in that case the labels claim too much, for the proof of distinctiveness demands greater detail and complexity of understanding than any mere label is capable of evoking. A purely detached approach to understanding the specificity of the EU in such capsule terms, therefore, tends towards opposite errors; either towards the easy indulgence of conceptual window-shopping or towards gratuitous and ultimately sterile disagreement.

Yet a more engaged approach to the question of definition is also available, and here the conceptual work matters much more. From an engaged perspective, the point of labelling is not one of passive taxonomy. The purpose is not simply to situate the European polity correctly within an inert classificatory scheme. Rather, it is to provide an active component in the understanding and ongoing construction of the EU project. The justification of such an approach might be threefold. In the first place, it might be a matter of technique. Here the federal idea offers a kind of epistemic key. It unlocks a rich fund of comparative and historical resources on how to do things in the federal way. These may be helpful in matters of grand constitutional design, but also in incremental institutional development and in legal decision-making more generally ${ }^{18}$. In the second place, the federal idea might possess an expressive significance. It might speak directly to the social and political identity of its recipients, conveying or suggesting a broader message to the EU's various audiences, internal and external, about the kind of attachments and expectations that are possible and appropriate for its

\footnotetext{
14 See P. SCHMITTER (1996).

15 See e.g. D. N. MacCormick (1999).

16 N. WALKER (2002), pp. 317-59.

17 As described By Jacques Delors in 1985. For discussion, see H. DrakE (2000), p. 5.

18 See e.g. D. ElaZAR.
} 
'members', as well as the kinds of attitudes to it and expectations of it that are possible and appropriate from the perspective of 'non-members'. In the third place, the federal idea might supply a deeper imaginative resource. It may paint in broader brushstrokes, indicating a more expansive philosophical justification for and guidance towards a certain type of legal or political arrangement. In short, if - as we emphatically should do for a polity which has developed in such an exponential manner and following such an unprecedented course - we continue to view the EU as a work in progress after nearly 60 years, federal thinking may speak to us in one or more different registers of engagement. It may speak to our know-how and instrumental calculations as constitutional engineers, to our affects and sensibilities as actors possessing or seeking to fashion particular forms of political belonging and identity, or to our deepest reflections on the art of the politically possible and desirable

Yet while the engaged perspective better explains why the ' $f$ ' word and its associates might be invoked in the 3D environment of the EU, it is a perspective that offers uneven rewards and which involves risk as well as opportunity. In this paper, I want to consider the mixed virtue of the engaged federal perspective in relations to certain key recent developments in the 3D territorial politics of the EU. In a nutshell, I want to argue that the invocation of federalism considered either as a technique of government or as a direct expression of an affective relationship between people and supranational polity is of limited or even negative value in the EU, but that federalism as a basis for imaginative reflection on the nature and proper trajectory of an unprecedented political configuration fares rather better. Here, indeed, the federal imagination provides a direct challenge to the state sovereigntist perspective set out above, but does so with complex, unpredictable and as yet unresolved effects given the powerful legacy of that sovereigntist perspective. In pursuing this point, I want to focus on a particularly topical and challenging part of the European federal puzzle. I want to concentrate on the third sub-state dimension of the EU's 3D 'federated' structure, and, in particular, how the development of the EU's federal imaginative example should and can alter the spirit in which new sovereignty claims at this level are both made and received.

\section{The Limits of EU federalism: technique and affect}

\section{(a) Federalism as governmental technique}

Let us start with federalism as technique. What, if anything, does the 'manual' of federal government have to offer as a guide to the EU? Even if we limit 
this inquiry to the 2D context of supranational and national levels, and the relationship between these two levels, the answer is not very much. The nub of the problem is that most thinking about federalism as a technique of institutional engineering, unsurprisingly, comes from the familiar context of the federal state. A glance at any checklist of the salient institutional features of federalism confirms this. Alongside the basic idea of a settled division of legislative competence and executive authority between the two levels of government, on such a list we would typically find the following; the supremacy of the federal constitution as the 'higher' source of the allocation of authority and the guarantee that the powers of neither level cannot be altered without the consent of that level; a supreme or constitutional court mandated to maintain the supremacy of the constitution by acting as final federal umpire in the demarcation of competences and also by supplying a minimum common standard of rights protection across the federation as a whole; some notion of double citizenship and allegiance to the two levels and spheres of the polity; the direct applicability of the laws of both levels upon these 'double citizens'; and the institutionalisation of some degree of shared rule within the central legislative framework, typically through a bicameral legislature in which the lower house represents the people of the polity as a whole and the upper house represents its constituent territorial parts.

If we look at the EU, some of these features are absent, and in these cases the federal manual is irrelevant and inappropriate as a guide. Other features are present, but in a form that suggests the differences from the federal state manual are as instructive as the similarities. To begin with those features that are absent, there is no supreme federal constitution in the EU (nor, importantly, would there have been one even if the abortive Constitutional Treaty project of 2003-5 had been successful, as its pedigree remained one of international law and as it did not purport to absorb and replace the backstop constitutional authority - and sovereign self-authorisation function - of member states $)^{19}$. Instead, there are separate and, where they tend to overlap, potentially competing claims to primacy on the part of supranational law, operating from Treaty foundations, and on the part of member state law, operating from state constitutional foundations. It follows from this basic absence of a canonical federal authority that there can be no supreme court mandated to maintain federal supremacy. Rather, mirroring and reinforcing the basic pluralism of authority, there are separate apex courts at EU (i.e. the Court of Justice of the European Union) and state levels, each jealously guarding the claim to ultimate authority within their own sphere of competence. This division of competence and of court jurisdiction also applies to the

19 On this, see e.g. N. WaLKER (2016). 
protection of rights, with the EU Charter of Rights - promulgated in $2000^{20}$ but not given direct legal authority until the Treaty of Lisbon 2009 - limited to those matters within EU competence, and so co-existing both with national constitutional rights catalogues and, in a further pluralizing complication, also with the older international framework of the Council of Europe Convention and Court of Human Rights, to which all members of the EU are required to subscribe and which the EU itself is under a standing ${ }^{21}$ but challenging ${ }^{22}$ legal obligation to join.

What of these checklist governmental features of which we can find some trace in the EU? Though not present at the outset, citizenship of the Union (conceived of as an automatic derivative of member state citizenship), and so dual Union-state citizenship, was introduced by the Treaty of Maastricht of 1991. Significantly, however, while well developed in the civil and social sphere, it remains underdeveloped in the political sphere where EU citizens of second member states are not allowed to vote for or stand in national elections in member states in which they are resident but lack citizenship. For its part, direct applicability has been a vital and distinctive (from the international norm) force of EU law from the outset, both present in the Treaties and championed in the early case law of the Court of Justice. But direct legislation (primarily through Regulations) remains only one institutional option alongside indirect legislation (primarily through Directives) requiring implementing measures in the member states. Finally, the image of a bicameral legislature has become more discernible in the complex institutional mosaic at the European centre, with a gradually strengthened European Parliament representing the European people as a whole, and both the European Council and the (functionally rotating) Council of Ministers representing the state parts. But the image remains both indistinct, blurred by the stubbornly low political salience of the European Parliament compared to its member state counterparts and complicated; first, by the 'lower chamber' European Parliament's continued disproportionate representation of small states in a manner that is more reminiscent of a regionally sensitive federal 'upper chamber'; secondly, by the fragmented and indirectly elected form of the 'upper chamber' of European Council and Council of Ministers; and, thirdly, by the heavy involvement of the non-elected but increasingly politicised European Commission as a 'third chamber' in the initiation phase of European legislation ${ }^{23}$.

20 Charter of Fundamental Rights of the European Union (2000/C 364/01).

21 TEU, Article 6(2).

22 See Opinion 2/13 (on accession of the EU to the ECHR), in which the Court ruled the Draft Agreement on Accession, itself the result of lengthy political negotiation. To be inconsistent with the broader legal and constitutional architecture of the EU.

23 See, e.g. the Spitzenkandidaten initiative of 2014, by which Juncker's appointment as new Commission President was pursuant to his being the nominated candidate of the majority of the newly elected European parliament - the first time such a linkage had been made. See e.g. H. MAHONY (2015). 
The inadequacy of the state federal manual as a technical guide to good government in the EU is reinforced if we adopt 3D vision and look, additionally, to the relationship between supra-state and sub-state levels. As already noted, analysis of the EU in federal terms has traditionally had little to say about this third dimension. Reflected in the popularity of labels such as Federation of States', and a 'federation d'état-nations', it has tended instead to concentrate on the 2D supra-state/state relationship. In some part this has to do with an (understandable) intellectual reflex to concentrate on those dimensions which bear a more obvious (though still, as we have seen, limited) family resemblance to the norm when exploring federal patterns, but it also has much to do with the EU's own historical 'regional blindness' 24 as an agreement between states in which the sub-state parts, regardless of how they might be recognised in domestic constitutional arrangements, simply did not register as separate actors. Yet, certainly since the institution of the Committee of the Regions almost quarter of a century ago, it has no longer been possible to disregard the sub-state dimension within the institutional profile of the EU. But, as will see below, the kinds of relationships that have developed between Brussels and the regions simply do not map onto the kind of technical checklist of federal governance we have been discussing.

\section{(b) Federalism as an expression of political identity}

If the language of federal technique fits awkwardly with the EU, the same is true of federalism as an expression of the affective relationship between people and polity. Again, the root case is the tendency to equate federalism with federal statehood.

European federalism as a self-conscious language of political identity has a complex heritage, in its modern EU-relevant form traceable back to the Ventatone Convention of 1941, the foundation of the Movimento Federalista Europeo two years later, and the inspirational role played by the Italian Eurocommunist and one time prisoner of war Alberto Spinelli in both. In this early phase, the symbolic meaning of federalism in the fledgling debate about a pan-European solution was as much corrective as constructive. It expressed a counterpoint to continental war, suggesting an alternative vision of Europe sufficiently integrated through common institutions and policies to rule out the prospect of any repetition of the century's two global conflicts.

The subsequent history of the 'f' word as an expressive factor in Europe's supranational project before and after the signing of the Treaty of Rome became more fragmented. One the one hand, the explicit version originally championed

24 J. BengoetXeA (2013), p. 235. 
by Spinelli gained some traction, and in 1984 Spinelli himself (by now an MEP) persuaded a majority of the European Parliament to endorse a Draft Treaty on the European Union. Spinelli's vocabulary was not only explicitly federalist, but also explicitly constitutionalist in its ambition to supply a popular founding document. However, this brand of 'constitutional federalism'25 both in 1984, and in later iterations - notably the Constitutional Treaty Project of 2003-5 - has tended in the final analysis to be defeated and to be eclipsed by what is sometimes called 'functional federalism'26. Functional federalism follows the alternative integration pathway famously set out by Jean Monnet, according to which supranational Europe would emerge sector-by-sector in a pattern of piecemeal progression. Common cause in the initial project of constructing an area of free trade and free movement would create spillover effects that would in time justify integration in other areas of social, economic and security policy. Where the ambition of constitutional federalism tends to be avowed, event-centred, exponential and teleological, therefore, the actual course of functional federalism has tended to be implicit, stepwise, incremental and reactive.

In the symbolic politics of European integration, there is no doubt that while the 'low road' of neo-functionalism has been followed, the 'high road' of constitutional federalism's explicit vision has suffered from its association with ideas of federal statehood. While there have been versions of constitutional federalism which do, indeed, tend in the direction of statehood, most of its prominent exponents have in fact emphasized the continuing importance of member state sovereignty alongside a more or less ambitious agenda of further integration ${ }^{27}$. Yet, especially from Maastricht onwards, Eurosceptic forces in the UK and elsewhere have been very effective in associating use of the ' $f$ ' word with EU-statist ambitions, thereby tapping into the fears of those whose political identity is closely tied to the nation state and who see a certain type of integrationist ambition as an existential threat to the nation state. So entrenched has this negative association become, indeed, that even where, in response to the post2008 fiscal crisis, there has been an unprecedented new wave of executive-led economic integration in the EU, with few exceptions ${ }^{28}$ those who have been in the vanguard of that change, in particular German Chancellor Merkel and French Presidents Sarkozy and Hollande, have assiduously declined to use the ' $f$ ' word to describe their plans. As one set of commentators put it, today 'federalism is

\footnotetext{
25 See A. Borriello and A. Crespy (2015).

26 Ibid.

27 As with Fischer's Federation of States, n8 above.

28 Notably, the erstwhile Commission President Barroso; see 'Barroso calls for an EU federation' Financial Times, 12 September 2012.
} 
both taboo and pervasive in French and German leaders' discourse'29. However much it may inform or accurately describe developments, in Europe's contemporary identity politics it is an influence or direction that dare not speak its name.

As we shall see, this emphatically does not mean that the EU is incapable of influencing the affective relationship between citizens and the polities with which they are associated. Indeed, as we come to explore the deeper structure of the federal imagination we will show how it assuredly does. All that should be claimed is that the direct self-attribution of the federal label by those who speak on behalf of the EU has become an increasingly unproductive expressive option in the arena of European identity politics.

\section{The Federal Imagination}

What then of federalism not as a tool-kit of good government in the EU, and not as a surface expression of a political form with which people may (or, more commonly, may not) identify, but as a deeper imaginative resource and means of reflecting on the nature and purpose of our legal and political arrangements in a manner oriented towards the more general 'federal' possibility of a combined order of self-rule and shared rule? Here we encounter more promising terrain. Within the European tradition of modern political and public law thought, alongside the dominant modern state-sovereigntist tradition first fully developed in the $16^{\text {th }}$ century writings of Jean Bodin, an alternative trail leads back to Johannes Althusius, the Calvinist political philosopher of the same era. Whereas the sovereigntist approach emphasized the primacy of the state system internationally and the indivisibility and 'top-down' pattern of sovereign authority domestically, in so doing encouraging the restrictive confederation-federal state duality of conventional federal wisdom, the Althusius approach stressed instead a 'bottom-up' covenantal view of human society ${ }^{30}$. According to this view, the political order as a whole is a compound association-of-associations established by citizens on the basis of their consent-grounded basic communities. In contrast to the sovereigntist approach, the image is one of a mosaic connecting different forms of community rather than of a unifying hierarchy, of evolved rather than imposed order, of an organic process rather than a reified state form.

The broad federal vision of a combined order of self-rule and shared rule, of course, has many and varied historical sources and influences ${ }^{31}$, and the point is not to accord any particular priority to Althusius in accounting for the

29 See Borriello and Crespy n25 above, p. 504.

30 For discussion, see e.g. D. ElaZAR (2001).

31 Ibid. See also Follesdal, n10 above. 
contemporary influence of federalist thinking in the European supranational context. Rather, it is to stress the long historical significance in Europe of an alternative projection of modern political society of which Althusius's thought was both reflection and reinforcing cause ${ }^{32}$, and which has continued in the institutional form of many modern European multinational states as well as through the example of key global precedents in the USA and elsewhere.

Although its genealogy is again complex and multi-faceted, the introduction of the concept of 'subsidiarity', which speaks to the same broader aspect of the legal and political imagination as does the historical lineage of federalism, into the general lexicon of EU law by the Treaty of Maastricht, is also revealingly suggestive of this continuity ${ }^{33}$. The Treaty version of the subsidiarity principle holds that other than in those limited areas where it has exclusive competence, 'the Union shall act only if and in so far as the objectives of the proposed action cannot be sufficiently achieved by the Member States, either at central level or at regional and local level, but can rather, by reason of the scale or effects of the proposed action, be better achieved at Union level'34. For present purposes what is most telling about this formulation is threefold. In the first place, there is the default presumption in favour of the more local level of authority in the absence of a special justification for central authority, a presumption that chimes with the covenantal emphasis on the primacy of the local community. In the second place, there is the specification of a graduated or spectral conception of authority - an attribute properly located at variable levels within a multi-layered set of possibilities depending on circumstances, rather than categorically assigned to one site or another. Again this chimes with the deeper image of federalism, in particular the idea of the structure of political authority as a multiform mosaic. In turn, this indicates a third and more particular significance. For, with its reference to the 'regional and local level', the concept of subsidiarity specifically penetrates below the level of the state in contemplating a more encompassing federal-style conception of layered authority.

\section{The EU Federal Imagination in 3D}

How then, in manner which can neither draw on the federal state manual nor style itself in explicitly federal terms, does the EU's treatment of the third level of

32 Including some of the earliest federations such as the Helvetic Federation (in Switzerland), the Holy Roman Empire and the United Netherlands.

33 For discussion, see N. WALKER (2015).

34 TEU Art. 5(3). 
sub-state authority specifically draw upon the federal imagination of a combined order of self-rule and shared rule?

As noted above, with the passing of the Maastricht Treaty of 1992, a Committee of the Regions emerged as a consultative body to the other institutions. Its somewhat marginal early role was improved under the Lisbon Treaty of 2009 , which requires the Commission, Council and Parliament to consult it on matters concerning local or regional government, and which also allows the Committee to challenge EU laws that may fall foul of the principle of subsidiarity ${ }^{35}$. Regions also benefit from their legal recognition as regions through access to European structural funds administered through their member states, and through rightsbased and anti-discrimination measures that guarantee linguistic and cultural protection for minority groups. More generally, the economic and political structure of a supranational union can provide avenues of opportunity to regions not available within the solitary state. Regions now have free access to a community-wide market of 500 million people, and these open frontiers can help promote joint economic activity and encourage cultural connections between regions. And alongside this horizontal network of 'paradiplomacy'36, there are also new political ties in the vertical structures of European governance, particularly through the European Free Alliance (of nationalist, regionalist and autonomist parties) in the European Parliament and the establishment of the informal Conference of European Regions with Legislative Power.

These institutional, regulatory, economic and political forms of encouragement of sub-state autonomy have recently begun to be reflected and reinforced at the constitutional level of EU law. Initially, this higher-level recognition was resisted not only due to the political weight of sovereign member weight interests in the making of supranational Europe, but also according to the deeper logic of international law. The principle of the international autonomy of the state has traditionally held that the state can organise itself in whichever way it chooses internally, provided it honours its international obligations. It followed from this that an international organisation such as the EU had neither right nor duty to examine, supervise or control how states configured themselves internally. A second principle of State personality reinforced this first principle by linking title to authority. Just as the state is the decisive judge of its own internal relations, in international law it is only states, or further entities created by states in the international domain, that are recognised as having legal standing in international law.

35 For an overview, see D. G Internal Policies 'The Role of National Parliaments in Regional Policy under the Treaty of Lisbon' http://www.europarl.europa.eu/webnp/webdav/users/malfons/public/REGI\%20 2012/pe438580_en.pdf.

36 See e.g. F. Aldiecon and M. Keating (1999). 
Gradually, however, this international law-driven orthodoxy of regional blindness in the constitutional structure of the EU has given way to a more active form of recognition. In the first place, the Court of Justice, reflecting and reinforcing the institutional and other developments set out above, has gradually come to accept a degree of constitutional, decisional and financial autonomy on the part of regions possessing a certain measure and status of political and administrative self-government. On account of their special position, such self-governing regions no longer fall foul of state aid or anti-discrimination rules in matters such as the raising of taxes and the payment of agricultural subsidies ${ }^{37}$. Secondly, the Treaty of Lisbon itself has added a clear duty on the part of the EU to respect the national identity of states, with specific reference to their 'fundamental structures, political and constitutional, inclusive of regional and local self-government' ${ }^{\prime 3}$. Cumulatively, these developments suggest that the meaning of respect for the institutional autonomy of states in international law, at least as viewed through the lens of EU law, is slowly being turned on its head. Far from actively precluding the EU from taking account of how the state organises itself internally, the relevant international principle has begun to be construed so as to incorporate such an expectation ${ }^{39}$.

\section{The Challenge of sub-state independence movements to the 3D perspec- tive}

The third dimension of EU federalism has assumed a new salience in recent years with the development of strong independence movements in Scotland, Catalonia, Flanders and other federal or quasi-federal regions of EU member states. In Scotland and Catalonia in particular, matters have come to a head. A constitutionally validated independence referendum in Scotland last September was narrowly lost (55-45\%), while a constitutionally non-validated plebiscite ${ }^{40}$ in Catalonia a few weeks later actually favoured independence. Subsequent electoral success for independentist parties in May (Scotland) and October (Catalonia) of 2015, together with the 'Brexit' referendum of June 2016 which

37 See e.g. Case C 88/03 Portugal v Commission [2006] ECR I-7155; Case C-428/07 Horvath v Secretary of State for Environment, Food and Rural Affairs [2009] ECR I-6355.

38 TEU Art. 4(2).

39 BengoetxeA, above n24.

40 On the Spanish Constitutional Court's refusal to recognize the constitutionality of a referendum in 2014, see V. Ferreres Cornella (2014); see also J. Garcia Oliva (2015).

The Scottish National Party won 56 out of 59 Scottish seats in the May 2015 UK general election, based upon $50 \%$ of the popular vote. 
advised against continuing EU membership of the wider UK of which Scotland is still part, has ensured that the question remains very much live in both places ${ }^{41}$.

In either case, the question of subsequent membership of the EU by the seceding state - the so-called 'internal enlargement' question ${ }^{42}$ - has loomed large. The independence movements have been largely pro-EU, and, certainly, their popular support has favoured continued EU membership. But the actual course and prospects for a transfer of membership in these unprecedented circumstances have remained stubbornly unclear. Should an independent (or aspiringly independent) Scotland or Catalonia follow the ordinary Treaty amendment procedure for existing Member States under Article 48 TEU in seeking to secure the continuing membership of its citizens? Or should it follow the conventional accession route for aspiring Member States under Article 49? Whichever route it followed, would that route imply certain success, or at least its strong expectation, and, better still for the supporters of independence, would it entail a rapid and seamless acknowledgement of Scotland's place at the European table? Does the Treaty's horizontal obligations of sincere co-operation and solidarity between Member States, together with the vertical framework of rights and responsibilities connecting the EU with its citizens, ground a legal duty on all parties to negotiate Scotland or Catalonia's entry in good faith ${ }^{43}$ And will Scotland's position be enhanced if and when Brexit goes ahead and independence becomes the only means to secure the continuing EU membership of Scottish citizens? Or should new internal states simply take their place at the end of a long queue of candidate states from Central Europe and beyond, with no legal basis for special treatment or consideration, and no guarantee or even legitimate expectation of eventual success? And tied up with these threshold questions, on what terms could new internal states expect to negotiate entry? In Scotland's case, the constitutional gravity of the referendum vote together with the peculiarities of the UK's semi-detached membership gave these questions a particularly pressing relevance. Could Scotland (as the supporters of independence wished) seek to rely on UK opt-outs on Schengen, or the Euro - the latter particularly important in light of the pro-independence campaign's tenacious commitment, against the opposition of the UK Government, to stick with the

41 In Catalonia, the pro-independence parties won 72 out of 135 seats in the regional election of September $25^{\text {th }}$ 2015, which had been presented by them as a 'de facto' plebiscite (a 'de jure' plebiscite having been forbidden under the ruling of the Spanish Constitutional Court [n7 above]). The result, however, was far from an unambiguous success for the independence camp as they won only $47.7 \%$ of the popular vote. See e.g. D. Gardner (2015). See also Garcia Oliva, n39 above.

42 See e.g. N. WaLkER (2016).

43 On which, see e.g. David Edward (2012). 
sterling currency? ${ }^{44}$ And would Scotland's prospects of relying on these opt-outs disappear if and when the Brexit process was concluded and the UK itself had left the EU club?

These ongoing developments undoubtedly provide a profound test of the EU's 3D federal imagination, posing hard questions concerning what difference the EU has made, what contribution it can or should continue to make, and what (if any) should be its public posture on these matters. Yet this same profound test also promises a dividend by enriching our broader thinking about the limits of the federal imaginary in a world in which a sovereigntist logic remain a powerful factor in international relations, and, conversely, about the limits of the sovereigntist imaginary in a world in which a federalist logic is becoming more powerful in both infra-state and transnational relations.

The basic challenge can be presented as follows. On the one hand, the EU, as we have seen, has helped stimulate the development of third-level regional political identity in its supranational context through its gradual and tentative unfolding of a broader federal vision, and, indeed, if we are to take its broader remit as an exercise in post-statist federal thinking seriously, this stimulating influence should be approved. On the other hand, that this encouragement should lead, by extension, to the articulation and pursuit of new claims in the old state sovereigntist register, would seem to challenge, and in one view, contradict, the basic premises of such post-statist federal thinking.

44 See e.g. The Scottish Government's independence manifesto Scotland's Future: Your Guide to an Independent Scotland (2013) chapter3 http://www.gov.scot/resource/0043/00439021.pdf.

Clarity on these matters would have allowed for a more informed assessment ahead of ' $D$ ' day by all involved in the drawn out constitutional drama - a more considered appraisal of the risks attendant upon the choice for or against an independent Scotland. But clarity was not in fact forthcoming. Instead, the emergence before the vote of a clear and precise legal picture of the membership prospects of an independent Scotland was probably always a naïve hope. There are, after all, no precedents for 'internal enlargement' of the EU following the separation of an existing member state, no Treaty provisions directly in point, and no obvious forum outside of the political process where a definitive statement of the relevant law can be supplied or enforced. (See e.g. S. DougLAs-Scott, 2014.) And even if we were to reach agreement on the best understanding of the relevant law, or at least to acknowledge some legal positions as more persuasive and widely supported than others, and even if we were to assume there was a forum in which the most persuasive version could be definitively pronounced, it is not clear how far that would take us. For most plausible interpretations of the relevant law seem in any case only to fill in some of the background and leave much to the discretion, negotiating position and even the strategy of conformity of the relevant parties. So, for example, the majority of informed opinion may favour the Article 49 route - the bespoke accession clause - over Article 48, (See e.g. RICHARD HOYLE, 2014) but whichever is chosen leaves much in the way of timing and terms to the negotiation of the Member States and the various supranational institutions. Similarly, we may agree that, as a new Member State, an independent Scotland would under present Treaty rules be required to commit in principle to membership of the Euro, but as membership is conditional on meeting various convergence criteria which are under the (partial) control of the states themselves, that still leaves a significant margin of manoeuvre to the new state in the post-accession phase. (See e.g. ANDREW ScotT, 2012). In a nutshell, then, even if legal clarity had been forthcoming, that would not have produced legal certainty of outcome, since the relevant law is concerned much more with process and conditional requirements than with final outcomes. 
A forcible statement of the view that such an extension would be self-contradictory, and should be recognised as such by the EU in a clear policy of non-admission of new internal members, has been put forward by Joseph Weiler in his recent interventions on Catalonia and Scotland ${ }^{45}$. He begins by noting that just as national minorities in existing Member States who presently enjoy extensive forms of individual and collective freedom have no automatic right to secede as a matter of general international law, so, too, the EU in its accession and general membership policy should not be expected to indulge the independence claims of these un-oppressed sub-state nations. To the contrary, the very ethos of integration, reconciliation and continental solidarity that has fed the European project from its post-War beginnings should cause the EU, and all those who endorse the best understanding of its broadly federalist foundations, to take a dim view of any separatist, and so necessarily sovereigntist, impulse that seems to betray these founding virtues. From this perspective, therefore, far from having a stronger claim than those external candidates who have benefited from the EU's extensive post-Cold War Enlargement, as has often been suggested or assumed by supporters of internal enlargement over (or at least alongside) external enlargement, those nations already comfortably nested inside the EU's Western European heartland should be refused a safe supranational haven if they insist on the path to independence.

Various counters may be suggested to the Weiler approach. In the first place it is in danger of not taking a people's own view of its preferred collective future seriously enough. Whether we are dealing with the Scottish or the Catalan case or that of any other national minority, should not more store than Weiler allows be set by an aspiring nation's own sense of what is the constitutionally adequate vindication of its desire for collective autonomy? If nothing short of independence is deemed sufficient from the perspective of the constituency in question as an affirmation of shared political identity, it is difficult to see why such a subjective collective aspiration should be summarily dismissed in favour of a supposedly objective standard of adequate individual and collective freedom - one that, incidentally, always leaves in successful place another and prior but far from necessarily morally superior claim to nation-statehood. The EU, after all, already respects these already established sovereign claims within its broader federal vision, and it might be argued that this is as much (or as little) a performative contradiction as the acceptance of new sovereign claims.

On the face of it, international law, with its high threshold of a 'right' to self-determination, serves both to reinforce the Weiler argument, and remind

45 On Scotland, see JosEPH WEILER (2015). This piece sparked wider debate on the blog in the week before the Scottish referendum. For my own contribution, see N. WALKER (2015). On Catalonia, see J. H. H. WEILER (2012). 
us of that same conservative sovereigntist orientation. Its establishment-biased concern has always been with the minimum necessary disturbance of the existing international distribution of sovereign authority rather than the fairest and fullest accommodation of self-determination claims. Yet international law today is becoming more fluid on this matter than first impressions suggest. There are, in fact, competing philosophies bubbling under its doctrinal surface ${ }^{46}$. The present position tends to reflect the Remedial Right or Just Cause theory, according to which secession is only justified if some basic injustice stands present and uncorrected, such as a historically unconsented annexation, a continuing lack of protection of the basic rights and security or economic interests of a region, a pattern of systematic group discrimination, or a breach of an existing agreement of autonomous self-government or of the protection of distinct collective rights ${ }^{47}$. Yet in a post-colonial age in which international law has gradually come to recognize and support the democratic tide in matters of state formation, this approach is increasingly challenged by a more generous Primary Right or Choice theory according to which any community which views itself as a distinct national community and which has a special association with a particular territory possesses a claim to sovereign self-determination ${ }^{48}$. And, in practice, there is evidence of a creeping convergence of these positions in the relevant jurisprudence. Since the landmark Quebec Secession ${ }^{49}$ decision of the Canadian Supreme Court some jurists have begun to proceduralise the right to self-determination into something like a right of a national group 'to be taken seriously' 50 in its efforts to secede from an existing state. That is to say, even though there continues to be no automatic entitlement absent a standing injustice, the articulation of a desire for independence on the part of a sub-state national group, ideally through the mechanism of referendum, should be sufficient to trigger a requirement on the part of the existing state to negotiate in good faith with the sub-state nation over their aspirations for independence.

But even if, notwithstanding these shifts in general international law and the conventional morality of international relations, a special case for the EU as an entity possessing and pursuing a unique historical mission to make internal secession unacceptable and unnecessary can be advanced along the lines advocated by Weiler, it seems unduly dogmatic to use this to justify a rigid policy against continued membership of new internal states. There are, after all, other

\footnotetext{
46 See e.g. S. Mancini (2012), pp. 483-7; A. PATten (2002).

47 See e.g. the many works of Allen Buchanan (2004); see also W. Norman (2006).

48 See e.g. D. Philpott (1995; 1998); Wellman (1995); H. Beran (1998).

49 Reference re Secession of Quebec [1998] 2 SCR 217. The emphasis here is again on clarity of legal process rather than certainty of outcome, to revert to a distinction drawn at n44 above.

50 See in particular, J. KLABBERS (2006); see also C. BeLl (2014).
} 
and rival views of the deeper purpose and distinct regional mission of the European Union, with the emergent 3D federal vision introduced above to the fore. The priority given in the Preamble to the TEU to the principle of subsidiarity, the deepening significance of EU citizenship as a horizontal relationship amongst persons as multi-level Europeans rather than state nationals, the growing institutional recognition of sub-state identity through the Committee of the Regions and various mechanisms of regionally sensitive distribution of supranational funds, reflect an alternative and more autonomy-friendly perspective.

$\mathrm{Bu}$ this merely restates the problem. How, if at all, do we reconcile these competing 'stretchings' of the federal imagination? They offer two quite distinct styles of post-state federalism, one protecting a modified form of national sovereignty and the other countenancing new sub-state sovereigntist projects? One cautious view would hold that the complex balance of reasons on either side, together with a prudential concern that the EU not express itself as the decisive authority on this matter - a concern closely related to the broader symbolic dangers, discussed above, of an assertive EU becoming typed as a federal state in the making - means that, regardless of the 'right' answer in political morality, the public policy of the EU on accession should surely remain agnostic.

The EU has in fact taken an agnostic approach. The Commission (mainly through its Presidency) alone amongst the European institutions has been prepared to speak on the matter, but in so doing has said as little as possible $^{51}$. Their attitude has been to avoid controversy and deflect responsibility by stressing the need to cleave to the existing framework of legal rules and political practice as a template of disinterested and deferential process. That is to say, their stance has been one of 'legalism plus', gesturing to the procedural rules, but also to the leeway for the exercise of political discretion on the part of the Member States these rules permit, as together supplying the appropriate decision pathway, and in so doing excluding themselves from any active influence over that decision and absolving themselves of any responsibility for it. The policy position that emerges from Brussels' attitude of prudential minimalism

51 As was Barroso's repeated tendency when President of the Commission. His warning of the possible negative reactions of some Member States, and the dangers this posed to the accession process, was most explicitly stated on UK nationwide television in the BBC's Andrew Marr show on February 17th 2014, sparking a very lively reaction. For comment, see N. WALKER (2015). The Commission's stance was somewhat softened later in the year when the then President Elect, Jean-Claude Juncker, remarked that, as an internal applicant, a newly independent Scotland, having completed a constitutionally recognized secession from the UK, would be deemed already to meet 'core-EU requirements' and so, to that very limited extent, would be treated as a special and separate case; http://www.scotsman.com/news/politics/ top-stories/independence-juncker-sympathetic-to-scotseu-bid-1-3482266. For fuller discussion, see N. WALKER (2015). 
I have described elsewhere as one of 'conservative neutrality'52, in which the state-protective orientation of domestic constitutional norms on secession and the equally state-centred slant of their own European procedures on accession are emphasized and their close adherence promised. In this perspective, the EU institutions, already uncomfortable under the heavy contemporary burden of unavoidable political judgment in matters as controversial as the sovereign debt crisis and (more recently) mass immigration, instead defer in the self-determination context to a process that inevitably (re)empowers the Member States themselves individually and collectively.

One ironic, and potentially self-defeating, consequence of this, however, is that, as substance need not follow form, the EU's formal deference to domestic constitutional norms permits substantively different outcomes. Scotland, in this perspective, has benefited from an increasingly permissive constitutional culture in the UK in which the Union state has come to accept the continuing right of it parts to self-determine their own future, whereas the Spanish federal constitution has remained firmly locked against the politically powerful claims for a referendum from its Catalan part. The EU's acquiescence in the national constitutional position on secession in each case implies an acceptance of quite different answers to the plebiscitary aspirations of two sub-state nations.

\section{Restaging the Federal Imagination}

Does this not, however, suggest a scenario in which the pursuit of the federal imagination to take account of an unprecedented 3D development is simply trumped by, and so becomes compromised by the EU's ideologically-rooted expressive timidity? Perhaps so, but perhaps, alternatively, neutrality could amount to more than this cautious pragmatic reflex. There is, after all, a significant difference between merely avoiding the question of principle for fear of courting political controversy, which seems to have largely characterized the EU's actual approach, and answering the question of principle through a position of considered neutrality in which, as set out above, the existence of reasonable alternative interpretations of the public philosophy of the EU means that it would be unwarranted for the EU to take a categorical stance one way or the other. What is more, and what is crucial, in any case the EU can contribute and should be understood as contributing something other to the Scottish debate, and to that of the sovereign aspirations of any European sub-state nation, than the role of ethical gatekeeper whose authority is dubious and, if exercised, liable to breed 
resentment and bring the authority of the EU itself into disrepute. Considered neutrality, in short, need not imply an absence of influence.

How is this so? If the EU's hands are tied in terms of what it says and does here, what it is as a political entity nevertheless has significance for the debate on secession. For, crucially, in ways some of which are little remarked but broadly experienced, the EU's very existence as a developing 3D federal formation alters the stakes of political nationalism. In the first place, and in material terms, by pooling significant sovereign powers above the state and encouraging new forms of recognition below the state the EU demonstrates that the choice between national independence and continued incorporation in another state is far from being an all-or-nothing affair. In particular, as we have seen, and as Weiler underlines, by supplying various economic and social rights and measures of non-discrimination it offers the kind of cosmopolitan freedom that guarantees against the systematic ill treatment of minority nations and nationalism within existing state forms. In the second place, however, and perhaps more importantly, by supplying a new level of political identity (including a new form of citizenship) and a new point of reference for interpreting national identity, the EU surely also changes the significance of national sovereignty and its alternatives for matters of political identity. Here the work of the federal imagination becomes closely linked to affective questions of belonging, but does so through a deeper adjustment of perspectives rather than through any expressive project of federal self-naming on the part of the EU. Just as 'independence in Europe', as in the Scottish nationalists' longstanding slogan, conveys a very different meaning and sense of collective identity than would, say, the 'separatism outside Europe's Northern edge' of a unattached Scotland, so too 'Britain in Europe' is much less isolationist than without its qualifier (as is currently threatened by those who have succeeded in their referendum campaign against continuing British membership of the EU continuing British membership of the EU) ${ }^{53}$, and 'Scotland-in-Britain-in Europe' suggest a much less subordinate native identity than merely 'Scotland in Britain'.

As the examples imply, the argument here cuts both ways. The protective presence of the EU certainly offers a spur to new projects of national sovereignty. Yet it also supplies a set of considerations that makes the project of new statehood less consequential, and, in the instant Scottish case, provided we could trust in continuing UK membership of a continuing EU (both of which statuses hang by a precarious thread as we enter 2017) less relevant, arguably unnecessary, and in the eyes of some sub-state nationalists at least, ultimately redundant. Of course, it is precisely this sense that the EU is materially and

53 See e.g. S. Douglas-ScotT (2014). 
symbolically adept at securing the kinds of guarantees and forms of individual dignity and collective recognition whose presence are generously accommodating of many species of sub-state nationalism and whose absence might otherwise fuel and justify independentist claims that lies behind Weiler's insistence that the EU should also be explicitly and concretely resistant to new forms of legal and political identity divisive of existing Member States. But, in my view, the first claim should be allowed to stand or fall on its own merits. The EU, as we have seen, simply lacks the legitimizing presence to play a robust directorial role in treating the internal secession question, but its background work of 'stage redesign', so to speak, of reframing how we see and experience the goods of political community in ways that are highly relevant to that same question, has nevertheless been profound.

The 'carrot' of current membership of an EU that is developing a strong post-state federal imagination, therefore, should be its own incentive, without the 'stick' represented by the raw threat of future exclusion. As we face the prospects of further and more intense pressure from European national movements, the supranational case for the accommodation of these sub-state nations within the existing pattern of statehood remains better served, and served with less prospect of collateral damage to the supranational project itself, by emphasizing the space for the expression and realization of national political interests that Europe offers in the here and now, rather than by dire warnings of privations to come for those that might opt otherwise.

In the final analysis, the EU cannot avoid receiving 'old' state-sovereigntist claims regarding the terms and conditions of membership, whether the authors of these claims are themselves old or new. What it can provide in response to these claims, and in anticipation of all future claims, is twofold. On the one hand, it can offer a considered neutrality that is careful not to over-reach its own legitimacy as a federal non-state. On the other hand, and more tellingly, it can continue with its pioneering, federal-imagination-stretching example in a novel 3D environment, subtly altering the texture and moderating the significance of such sovereigntist claims and so reducing the material or symbolic stakes for those who stand on one side or other of the identity struggles that inevitably attend the making and remaking of political community.

\section{Bibliography}

AvbelJ, M., "Theory of European Union”, European Law Review, vol. 35, 2011, pp. 818-36.

Beaud, O., Théorie de la Fédération, Presses Universitaires de France, Paris, 2007. 
BeLL, C., "What we talk about when we talk about international constitutional law", Transnational Legal Theory, vol. 5, 2004, pp. 241-284.

BengoetXeA, J., "Autonomous Constitutional Regions in a Federal Europe", in Federalism in the European Union, E. Cloots, G. De Baere and S. Sottiaux (eds.), Hart, Oxford, 2013, pp. 230-48.

Beran, H., "A Democratic Theory of Political Self-Determination for a New World Order", in Theories of Secession, P. Lehning (ed.), Routledge, London, 1998, pp. 32-59.

Borriello, A./Crespy, A., "How to not speak the F- word: Federalism between mirage and imperative in the euro crisis", European Journal of Political Research, vol. 54, 2015, pp. 502-524.

Buchanan, Allen, Justice, Legitimacy and self-determination, Oxford University Press, Oxford, 2004.

Burgess, M., Federalism and European Union: The Building of Europe, 1950-2000, Routledge, London, 2000.

Dehousse, R., "European Institutional Architecture After Amsterdam: Parliamentary System or Regulatory Structure?", Common Market Law Review, vol. 35, 1998, pp. 595-627.

DouglAS-ScotT, S., "British Withdrawal from the EU: An existential threat to the United Kingdom?", Scottish Constitutional Futures Forum Blog, October 2014; http://www.scottishconstitutionalfutures.org/OpinionandAnalysis/ ViewBlogPost/tabid/1767/articleType/ArticleView/articleld/4411/Sionaidh-Douglas-Scott-British-Withdrawal-from-the-EU-an-Existential-Threat-to-the-United-Kingdom.aspx.

Drake, H., Jacques Delores: Perspectives on a European Leader, Routledge, London, 2000.

EDWARD, David, "Scotland and the European Union", Scottish Constitutional Futures Forum Blog December 2012; http://www.scottishconstitutionalfutures. org/OpinionandAnalysis/ViewBlogPost/tabid/1767/articleType/ArticleView/ articleld/852/David-Edward-Scotland-and-the-European-Union.aspx

ElazAr, D., Constitutionalizing Globalization: The Postmodern Revival of Confederal Arrangements, Rowman and Littlefield, Lanham, 2008.

ElaZAR, D., "The Significance of Federalism in Redesigning Constitutional Systems", Jerusalem Center for Public Affairs; available at http://www.jcpa.org/ dje/articles/fed-constsys.htm.

ElazAR, D., "The United States and the European Union: Models for their epochs", in The Federal Vision, K. Nicolaidis and R. Howse (eds.), Oxford University Press, Oxford, 2001, pp. 31-53.

FABBrinI, S., Compound Democracies: Why the United States and Europe are Becoming Similar, Oxford University Press, Oxford, 2007. 
Ferreres Cornella, V., "The Spanish Constitutional Court Confronts Catalonia's 'Right to Decide' (Comment on the Judgment 42/2014)', European Constitutional Law Review, vol. 10, 2014, pp. 571-590.

FollesDal, A., Federalism Stanford Encyclopedia of Philosophy; available at http://plato.stanford.edu/entries/federalism.

García Oliva, "Catalonia in Spain: The Significance of the 25th September 2015 Elections", UK Constitutional Law association Blog; July 2015 http:// ukconstitutionallaw.org/2015/07/24/javier-garcia-oliva-catalonia-in-spain-the-significance-of-the-25th-september-2015-elections.

GLencross, A., What Makes the EU Viable? European Integration in the Light of the US Antebellum Experience, Basingstoke, MacMillan, 2009.

Hueglin, T./ Fenna, A., Comparative Federalism: A Systematic Inquiry, Broadview Press, Peterborough, 2006.

KLABbers, J., "The Right to be Taken Seriously: Self-Determination in International Law", Human Rights Quarterly, vol. 28, 2006, pp. 186-206.

Law, J., "How Can we Define Federalism?", Perspectives on Federalism, vol. 5, number 2, 2013, pp. 89-120.

MancinI, S., "Secession and Self-Determination", in The Oxford Handbook of Comparative Constitutional Law, M. Rosenfeld and A. Sajo (eds.), Oxford University Press, Oxford, pp. 481-500.

McCormick, J., Questioning Sovereignty: Law, State and Nation in the European Commonwealth, Oxford University Press, Oxford, 1999.

McCormick, J., European Union Politics, Palgrave, Basingstoke, 2011.

McKay, D., Designing Europe: Comparative Lessons from the Federal Experience, Oxford University Press, Oxford, 2001.

Norman, W., Negotiating Nationalism; Nation Building, Federalism and Secession in the Multinational State, Oxford University Press, Oxford, 2006.

PatTen, A., "Democratic Secession from a Multinational State", Ethics, vol. 112, 2002, pp. 558-586.

PHILPOT, D., "In Defense of Self-Determination", Ethics, vol. 105, 1995, pp. 352$-85$.

PHILPOT, D., "Self-Determination in Practice", in National Self-Determination and Secession, M. Moore (ed.), Oxford University Press, Oxford, 1998, pp. 79-102. PIRIS, J. C., "The European Union: Towards a New Form of Federalism?", in Patterns of Regionalism and Federalism: Lessons for the UK, J. Fedtke and B. Markesinis (eds.), Hart, Oxford, 2006, pp. 69-87.

SCHMITTER, P., "If the Nation-State Were to Wither away in Europe, What Might Replace It?", in The Future of the Nation State, S. Gustavsson and L. Lewin (eds.), Nerenius \& SanteYus, Stockhom, 1996, pp. 90-131.

Sснüтze, R., European Constitutional Law, Cambridge University Press, 2012. 
ScotT, A., "An Independent Scotland Could not be required to adopt the Euro as its Currency", Scottish Constitutional Futures Forum Blog, November 2012; http://www.scottishconstitutionalfutures.org/OpinionandAnalysis/ ViewBlogPost/tabid/1767/articleType/ArticleView/articleld/480/Drew-Scott-An-Independent-Scotland-Could-Not-be-Required-to-Adopt-the-Euro-as-its-Currency.aspx.

WaLker, N., "Beyond Secession? Law in the Framing of the National Polity", in Nationalism and Globalisation, S. Tierney (ed.), Hart, Oxford, 2015, pp. 155$-84$.

WaLkER, N., "Constitutional Pluralism Revisited", European Law Journal, vol. 26, number 4, 2016 (forthcoming).

WalkER, N., "Hijacking the Debate", Scottish Constitutional Futures Forum Blog, February 2015; http://www.scottishconstitutionalfutures.org/OpinionandAnalysis/ViewBlogPost/tabid/1767/articleType/ArticleView/articleld/3068/ Neil-Walker-Hijacking-the-Debate.aspx.

WaLKER, N., "Internal enlargement in the European Union: beyond Legalism and Political Expediency", in Troubled Membership in the European Union, C. Closa (ed.), forthcoming, Cambridge University Press, 2016); also available at http://papers.ssrn.com/sol3/papers.cfm?abstract_id=2676025.

WALKER, N., "Scotland and the EU: A Comment", Verfassungsblog, September 2015; http://www.verfassungsblog.de/scotland-eu-comment-neil-walker/\#. Vg5BlvlVhBc.

WALKER, N., "Subsidiarity and the Deracination of Political Community", SSRN (2015); available at https://www.google.co.uk/webhp?sourceid=chrome-instant\&ion $=1$ \&espv $=2 \&$ ie $=U T F-8 \# q=$ walker $\% 20$ subsidiarity $\% 20$ and $\% 20$ the\%20deracination.

WaLKER, N., "The Idea of Constitutional Pluralism", Modern Law Review, vol. 65, 2002, pp. 317-59.

Wallace, W., "Government Without Statehood: The Unstable Equilibrium", in Policy-making in the European Union, H. Wallace and W. Wallace (eds.), Oxford University Press, Oxford, 1996, pp. 439-60.

WatTs, R., "Federalism, Federal Political Systems and Federations", Annual Review of Political Science, 1, 1998, pp. 117-37.

WEILER, Joseph, "Catalonian Independence and the European Union", European Journal of International Law, vol. 23, 2012, pp. 909-913.

WEILER, Joseph, "Scotland and the EU: A Comment", Verfassungsblog, September 2015; http://www.verfassungsblog.de/scotland-eu-comment-joseph-h-h-weiler/\#.VgJnup1waUk

Wellman, C., "A Defence of Secession and Political Self-Determination", Philosophy \& Public Affairs, vol. 24, 1995, pp. 142-171. 